\title{
RANCANG BANGUN MESIN PENGADUK ADONAN AMPIANG
}

\author{
Eko Sulistyo ${ }^{1}$, Eko Yudo ${ }^{2}$ \\ ${ }^{1}$ Program Studi Teknik Elektronika dan Informatika \\ ${ }^{2}$ Program Studi Teknik Perawatan dan Perbaikan Mesin \\ Politeknik Manufaktur Negeri Bangka Belitung \\ Kawasan Industri Air Kantung Sungailiat - 33211 \\ Telp. (0717) 93586, Fax. (0717) 93585 \\ Sulistyo.eko@gmail.com
}

\begin{abstract}
Ampiang or crackers ampiang is typical of Bangka original food made from tapioca, fish, pure water, salt and food flavorings. In the process of making ampiang, there is an obstacle, that is in the process of mixing spices, fish and flour. Mixing or stirring the dough by hand by rotating the dough until the dough is ready to be used takes a long time. To overcome the above problems researchers made kneading ampiang horizontal type with a capacity of $10 \mathrm{~kg}$. The purpose of the research is to get the dough mixing uniformity percentage of $100 \%$ and $100 \%$ increased production time. The stages of the research are the of collecting data through surveys, questionnaires, interviews, and literature. The next step is data process, manufacture and selection of alternative concept, tool making and assembling, testing and analysis. In making the selection of alternative concepts and decided machine made with size $99 \times 66 \times 90 \mathrm{~cm}$, using the motor 1PK and design mixer horizontal type. The results show the machine is capable to knead the $10 \mathrm{Kg}$ dough of ampiang in 3 minutes and dough mixing uniformity percentage of $100 \%$.
\end{abstract}

Keywords: ampiang, dough, horizontal type

\section{Abstrak}

Ampiang atau kerupuk ampiang adalah makanan asli khas Bangka yang terbuat dari tapioka, ikan, air, garam dan perasa. Dalam pembuatan ampiang kendala yang dihadapi adalah dalam proses pengadukan bumbu, ikan dan tepung. Pencampuran atau pengadukan adonan menggunakan tangan dengan cara adonan diputar dan dibalik sampai adonan ampiang benar-benar merata sehingga prosesnya memerlukan waktu yang lama. Untuk mengatasi permasalahan diatas peneliti membuat alat pengaduk adonan ampiang tipe horisontal dengan kapasitas $10 \mathrm{Kg}$. Tujuan dari penelitian adalah mendapatkan hasil Prosentase keseragaman pencampuran adonan 100\% dan waktu produksi meningkat 100\%. Tahapan-tahapan penelitian adalah dengan cara pengumpulan data melalui survey, kuisioner, wawancara dan studi pustaka. Langkah selanjutnya adalah pengolahan data, pembuatan konsep dan pemilihan alternatif, pembuatan alat dan assembling, ujicoba dan analisa. Dalam pembuatan konsep dan pemilihan alternatif diputuskan mesin dibuat dengan ukuran $99 \times 66 \times 90 \mathrm{~cm}$, menggunakan motor penggerak 1PK dan desain pengadok tipe horisontal. Hasil penelitian menunjukkan mesin mampu mengadok adonan ampiang $10 \mathrm{Kg}$ dalam waktu 3 menit dan prosentase keseragaman pencampuran adonan $100 \%$.

Kata kunci: ampiang, adonan, tipe horisontal

\section{PENDAHULUAN}

Ampiang atau kerupuk ampiang adalah makanan asli khas Bangka yang terbuat dari tapioka, ikan, air, garam dan perasa. Jenis ampiang ini sangat beragam. Keragaman jenis ampiang dikarenakan adanya variasi bentuk proses pembuatan dan pencetakannya. Berdasarkan proses pembuatan dan pencetakannya, ampiang dikelompokkan menjadi dua jenis yaitu ampiang dengan bentuk irisan bulat tipis dengan diameter $7 \mathrm{~cm}$ dan diameter $10 \mathrm{~cm}$. Proses pembuatan ampiang dibagi menjadi beberapa tahap yaitu: proses penggilingan ikan berfungsi untuk menghancurkan daging ikan menjadi rata setelah 
itu dilanjutkan dengan proses pencampuran bahan yaitu mencampurkan daging ikan dengan tepung tapioka, air, garam dan bahan penyedap $[2,4,5]$. Setelah proses pencampuran bahan selesai, dilanjutkan dengan proses pengepresan dan pencetakan yang disesuaikan dengan ukuran yang diinginkan. Proses terakhir adalah pengorengan dan pengepakan.

Kualitas ampiang ditentukan oleh jenis dan jumlah ikan yang digunakan. Ikan yang biasa digunakan dalam proses pembuatan ampiang adalah jenis ikan laut seperti ikan tengiri, udang dan ikan ciu. Menurut Anonymus (1982), jumlah ikan atau udang yang digunakan dalam pembuatan ampiang akan menentukan rasa dan kadar protein ampiang yang dihasilkan.

Pesatnya perkembangan industri ampiang di Pangkalpinang memberikan dampak yang positif terhadap perkembangan makanan tradisional ini dan Pangkalpinang merupakan salah satu pusat daerah sentra pembuatan dan pengolahan ampiang yang memiliki potensi untuk dikembangkan lebih baik lagi khususnya dalam perencanaan dan pengelolahan produksi yang memerlukan adanya teknologi mesin pengaduk adonan secara otomatis [1,6] sehingga dapat memproduksi ampiang dengan kapasitas yang direncanakan sebelumnya.

\section{METODE PENELITIAN}

Metode penelitian ini dengan menggunakan perencanaan dan pembuatan serta uji coba mesin yang dibuat, Adapun flow chart metedologi penelitian yang digunakan sebagai berikut:

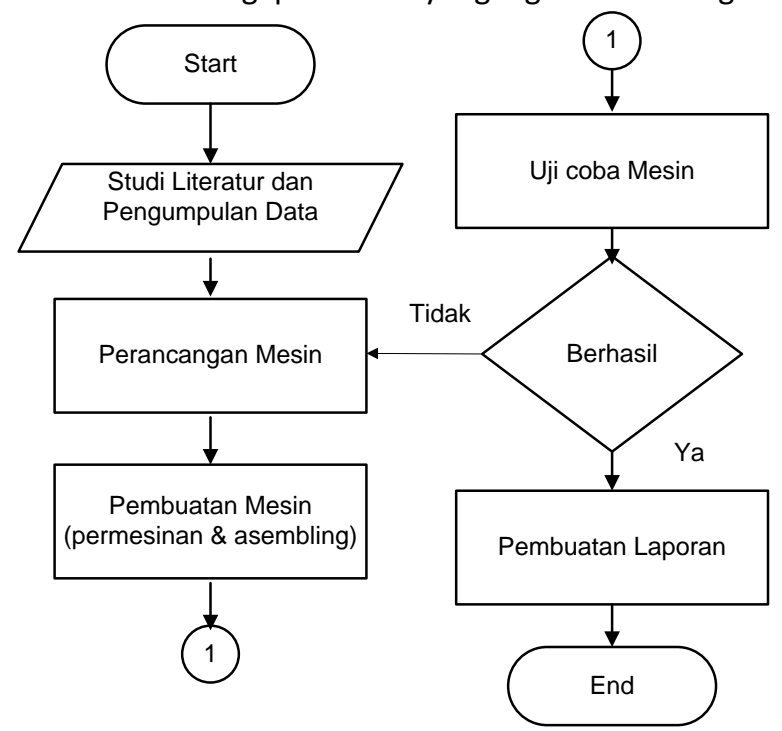

Gambar 1. Flow chart metedologi penelitian

\subsection{Studi Literatur dan Pengumpulan Data}

Pada penelitian ini literatur-literatur yang digunakan sebagai acuan permasalahan yang akan diteliti yaitu buku, website dan wawancara langsung dengan narasumber yang berkaitan ampiang dan proses pembuatannya.

\subsection{Perancangan mesin}

Perancangan mesin dimaksudkan untuk membuat desain mesin yang akan dibuat sesuai dengan hasil studi literatur [3] dan wawancara dengan pengguna. Adapun perancangan mesin yang akan dibuat memiliki spesifikasi sebagai berikut :

- Kapasitas mesin pengiling daging ayam 10 - $15 \mathrm{~kg}$ per proses dengan waktu 2 sampai 3 menit per proses.

- Ukuran mesin yang dibuat : $99 \times 66 \times 90 \mathrm{~cm}$.

- Motor penggerak menggunakan motor kapasitas 1 PK yang digunakan pada penggerak mesin.

- Bahan mesin yang digunakan:

- Rangka dibuat dari ST 37, profil L, plat $10 \mathrm{~mm}$ dan $12 \mathrm{~mm}$

- Mesin penggiling bahan mild Steel sehingga tahan karat

- Roda bahan karet sehingga mesin bisa dipindah-pindahkan. 
Penggambaran dalam perancangan mesin dilakukan dengan software CAD sebagai media bantu dalam perancangan. Setelah proses perancangan mesin, peneliti berdiskusi dengan pengguna apakah sesuai dengan yang diinginkan, jika sesuai dilanjutkan dengan proses pembuatan mesin.

\subsection{Pembuatan Mesin}

Pembuatan mesin dilakukan di bengkel mekanik Politeknik manufaktur Negeri Bangka Belitung. Pengerjaan mesin disesuaikan dengan bagian yang dikerjakan dan pengerjaan mesin menggunakan mesin bor, mesin frais, mesin bubut, mesin las, mesin gerinda dan ruang fabrikasi.

\subsection{Pengujian Mesin}

Pengujian mesin dimaksudkan untuk menganalisa performa mesin yang sudah dibuat apakah sesuai dengan tujuan yang diharapkan atau belum. Adapun pengujian mesin yang dilakukan adalah:

- Prosentase keseragaman hasil adonan kehalusan daging yang diinginkan.

- Waktu pengaduk adonan yang dilakukan dalam menit.

\section{HASIL DAN PEMBAHASAN}

Mesin pengaduk adonan ampiang yang dirancang dan dikonstruksikan dalam penelitian ini mempunyai beberapa bagian utama yang mendukung operasional kerjanya, yaitu motor penggerak, sistem rangka (frame), sistem transmisi, dan sistem pengadok adonan. Perancangan mesin yang dibuat dapat dilihat dalam gambar dibawah ini:
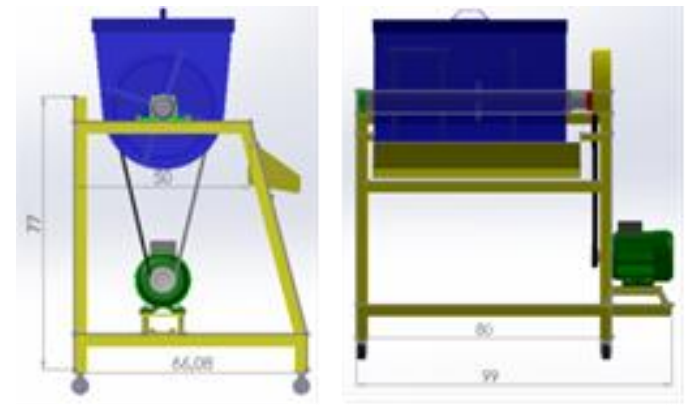

Gambar 2. Rancangan mesin pengaduk adonan ampiang

Sedangkan hasil pembuatan akhir mesin sesuai rancangan terlihat pada gambar 4 dibawah.

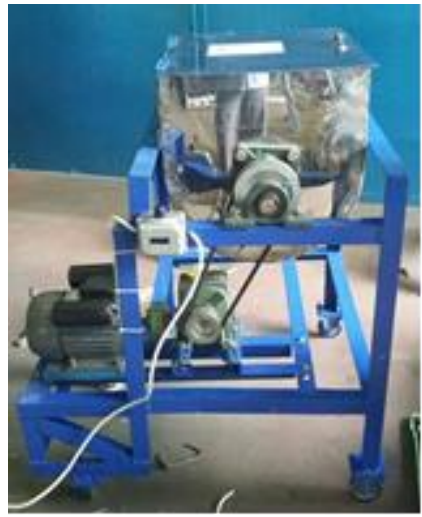

Gambar 3. Pembuatan akhir mesin pengaduk adonan ampiang

\subsection{Sistem Transmisi}

Sistem transmisi yang digunakan pada mesin pengaduk adonan ampiang ini adalah sistem transmisi sabuk dan puli. Puli yang digunakan memiliki diameter 3 dan 6 inchi. Sistem transmisi yang dirancang adalah putaran akhir untuk memutar adonan ampiang.Ukuran belt dan diameter pulley diketahui dengan menggunakan rumus: $\mathbf{D 1 . N 1}=\mathbf{D 2}$. N2

$\mathrm{D} 1$ = diameter pulley pertama $(\mathrm{m}), \mathrm{N} 1$ = putaran pulley pertama $(\mathrm{rpm})$ 
Perhitungan putaran puli dihitung sebagai berikut: D1 = diameter poros motor = 3 inchi, $\mathrm{N} 1=$ putaran motor $=1400 \mathrm{rpm}, \mathrm{D} 2$ = diameter poros puli1 = 6 inchi, N2 = putaran pada puli1 .

Sedangkan reducer yang dipakai adalah 1:50, maka putaran motor $(\mathrm{N} 1)=1400 / 50=28 \mathrm{rpm}$, dari perhitungan N1, maka N2 dapat dihitung sebagai berikut: N2=(3 28$) / 6=14 \mathrm{rpm}$. Dari hasil hitungan didapatkan putaran pada pengaduk adonan adalah $14 \mathrm{rpm}$.

\subsection{Pengaduk/Pengadon Ampiang}

Bagian pengaduk/pengadon ampiang berfungsi untuk mengaduk adonan ampiang supaya adonan menjadi rata. Adapun bentuk adonan dibuat bersirip dengan jarak sirip 1 dengan yang lainnya adalah $100 \mathrm{~mm}$ dan tinggi $120 \mathrm{~mm}$ terlihat dalam Gambar 4 dibawah:

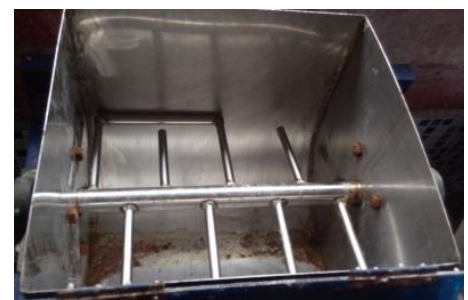

Gambar 4. Pengaduk/pengadon ampiang

\subsection{Pengujian Mesin}

Pengujian mesin dilakukan untuk menguji apakah mesin sudah sesuai dengan tujuan yang diharapkan atau belum. Pengujian dilakukan di bengkel Polman Babel, hasil pengujian terlihat dalam Gambar 6 :

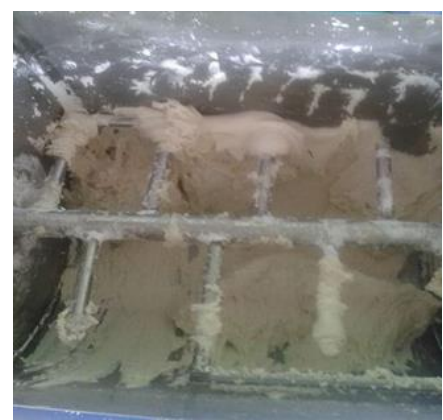

Gambar 5. Proses pengujian mesin pengaduk adonan

Dari hasil pengujian didapatkan data pengujian dalam tabel 1 sebagai berikut:

\begin{tabular}{clll} 
Tabel 1 Hasil pengujian waktu dan keseragaman mesin pengaduk adonan ampiang \\
\hline No & Uraian Kegiatan & $\begin{array}{l}\text { Menggunakan cara } \\
\text { manual }\end{array}$ & $\begin{array}{l}\text { Menggunakan } \\
\text { mesin pengaduk }\end{array}$ \\
\hline 1 & $\begin{array}{l}\text { Waktu pengaduk } \\
\text { adonan yang } \\
\text { dilakukan dalam } \\
\text { menit }\end{array}$ & 30 menit dalam $5 \mathrm{~kg}$ & $\begin{array}{l}3 \text { menit dalam } 10 \\
\mathrm{~kg}\end{array}$ \\
& $\begin{array}{l}\text { Prosentase } \\
\text { keseragaman } \\
\text { hasil adonan }\end{array}$ & $80 \%$ & $100 \%$ \\
\hline
\end{tabular}

Pada tabel 1 dapat dianalisa kapasitas pengaduk adonan ampiang dengan menggunakan manual menghasilkan $5 \mathrm{~kg}$ dalam waktu 30 menit, dan prosentase keseragaman kehalusan pengadon adonan 
ampiang yang dihasilkan 80 \%. Bila dibandingkan dengan menggunakan mesin didapatkan hasil jauh lebih besar yaitu dalam 3 menit menghasilkan $10 \mathrm{~kg}$.

\section{SIMPULAN}

Dari hasil uji coba dan analisa data yang didapat, Mesin pengaduk adonan ampiang dapat berfungsi dengan baik dan sesuai dengan tujuan yang diinginkan. Identifikasi karakteristik mesin pengaduk adonan ampiang dapat mengaduk adonan ampiang sebanyak $10 \mathrm{~kg}$ dalam 3 menit atau meningkat lebih dari $100 \%$ dan keseragaman hasil pengadukan merata dengan hasil $100 \%$

\section{DAFTAR PUSTAKA}

[1]. Polman Timah, T., 1996. Ilmu Kekuatan Bahan 1, Politeknik Manufaktur Timah.

[2]. Partu, 2010. Rancang Bangun Mesin penggiling daging, Laporan Akhir Tugas Akhir, Politeknik Manufaktur Timah.

[3]. Suhendra, Wahyudi, Laurensus Lubis, 2010. Rancang Bangun Mesin Pencetak Kerupuk Getas, Laporan Akhir Tugas Akhir, Politeknik Manufaktur Timah.

[4]. Wan Andriansyah, Hamzah, Murdianto, Andi kurnia, 2009. Rancang Bangun blender bumbu masakan kapasitas 10 kg, Laporan Akhir Tugas Akhir, Politeknik Manufaktur Timah.

[5]. Randi Felani, Deo Prasetya, Iga Pratama 2012. Rancang Bangun Mesin Penghancur Kepala CumiCumi, Laporan Akhir Tugas Akhir, Politeknik Manufaktur Timah.

[6]. Darmawan Harsokoesoemo, 2004, Pengantar Perancangan Teknik, ITB: Bandung 